\title{
PRODUCTION STRUCTURE OF MAIN COMMERCIAL TREE SPECIES IN A MANGROVE FOREST IN EAST SUMATERA, INDONESIA
}

\author{
CECEPKUSMANA*) \\ Faculty of Forestry, Bogor Agricultural University, Bogor, Indonesia
}

and

HIROYUKI WATANABE

Faculty of Agriculture, Kyoto University, Kyoto 606, Japan

\begin{abstract}
Production structure of main commercial tree species was studied in a mangrove forest in East Sumatera, Indonesia. This research was carried out in January 1991 using the estimation of standing biomass with stratified clipping method in order to know the production structure of the main commercial tree species in this mangrove forest, i.e. Rhizophora apiculata, Bruguieraparviflora and B. sexangula.

The results obtained show that $R$. apiculata tended to have a sparser foliage of thicker leaves along the stem than $B$. parviflora or B. sexangula; therefore, R. apiculata is regarded as a shade-intolerant tree species. In contrast, either $B$. parviflora or $B$. sexangula tended to have a larger proportion of leaves and branches along the stem; consequently, those species are recognized as shade-tolerant tree species.
\end{abstract}

\section{INTRODUCTION}

A substantial proportion of about $81000 \mathrm{~km}$ coastal line in Indonesia is covered by mangrove formations of various extents, from several meters to several kilometers (Soegiarto 1979). In terms of tree size and extent, mangroves are more developed in the five big islands, i.e. Java, Sumatera, Kalimantan, Sulawesi, and Irian Jaya (Darsidi 1984). In Sumatera, the mangrove covers an area of 667000 ha of which 276000 ha are distributed in Riau. Recently, about 87000 ha of mangrove forest in Riau have been designated as forest concession areas belonging to the Bina Lestari Company (42 000 ha), Thai Rayvithi Company (40 000 ha) and Silva Saki Company (5000 ha).

For many years, the mangrove trees in Riau were cut for fuelwood and used for charcoal either by forest concessionaires or local people inhabiting the region surrounding the mangroves. However, recently, most of the commercial tree species, especially Bruguiera spp. and Rhizophora apiculata are being exploited for the production of chipwood.

*)Present address: Faculty of Agriculture, Kyoto University, Kyoto 606, Japan 
It is highly necessary to establish a proper management system based upon biological knowledge to secure a sustained yield of mangrove resources. Therefore, the production structure of mangrove tree species must be studied to understand the biological characteristics of mangroves.

This research was undertaken in an attempt to analyze the production structure of the main commercial tree species (Bruguiera parviflora, B. sexangula and $R$. apiculata) in the mangrove forest of Talidendang Besar, Riau, East Sumatera.

\section{STUDY AREA AND METHODS}

This research was carried out in January 1991 in a mangrove forest concession area belonging to the Bina Lestari Company at Talidendang Besar (Long. 103 $28^{\prime}$ to $103^{\circ} 48^{\prime} \mathrm{E}$, Lat. $0^{\circ} 21^{\prime}$ to $1^{\circ} \mathrm{N}$ ), which lies on the east coast of Sumatera, Riau Province, Indonesia (Fig. 1).

No meteorological data were available for Talidendang Besar. The rainfall data of Mandah, the nearest area to Talidendang Besar, provide a good approximation of the climatic conditions (Fig. 1). The average annual rainfall is about $1335 \mathrm{~mm}$. According to the Schmidt and Ferguson system (1951), the climate of this area belongs to the type $\mathrm{B}$ rainfall with seven wet, two dry and three humid months.

The mangrove forest in this area is characterized by the Bruguiera species. The seaward fringe is strongly dominated by $B$. parviflora and landward zones are numerically dominated by $B$. sexangula. In the transition zone with a fresh-water swamp forest, the stand of $B$. sexangula is invaded by Nypa fruticans, in which a few large individual trees of $R$. apiculata form an emergent layer above an even canopy of $B$. sexangula. In this zone, a few trees of a marginal species, Ficus benjamina, occur in open areas created by fallen or dead trees and sometimes intermingled with $N$. fruticans along the river bank.

Sample trees of B. parviflora, B. sexangula and $R$. apiculata which have similar diameter sizes were felled. Stem diameter at breast-height (DBH) and tree height of sample trees were $20.1 \mathrm{~cm}$ and $19.4 \mathrm{~m}$ for $B$. parviflora, and $19.2 \mathrm{~cm}$ and $17.6 \mathrm{~m}$ for $B$. sexangula, respectively. However, the diameter at $20 \mathrm{~cm}$ above the highest prop-roots and the height of a felled sample tree of $R$. apiculata were $19.5 \mathrm{~cm}$ and $22.8 \mathrm{~m}$, respectively.

Sample trees were felled at ground level and cut into horizons of $1 \mathrm{~m}$ length along the stem. Fresh weight of stems, branches, flowers and fruits, and leaves of each horizon were separately weighed. A small sample of each organ from each horizon was taken and dried in an oven at $80^{\circ} \mathrm{C}$ for 48 hours to obtain a constant dry weight. The leaf area of a small sample of leaves from each horizon was measured with a leaf-area meter (Type AAM-7, Hayashi Denko). 
Production structure of main commercial tree species - Cecep Kusmana \& Hiroyuki Watanabe

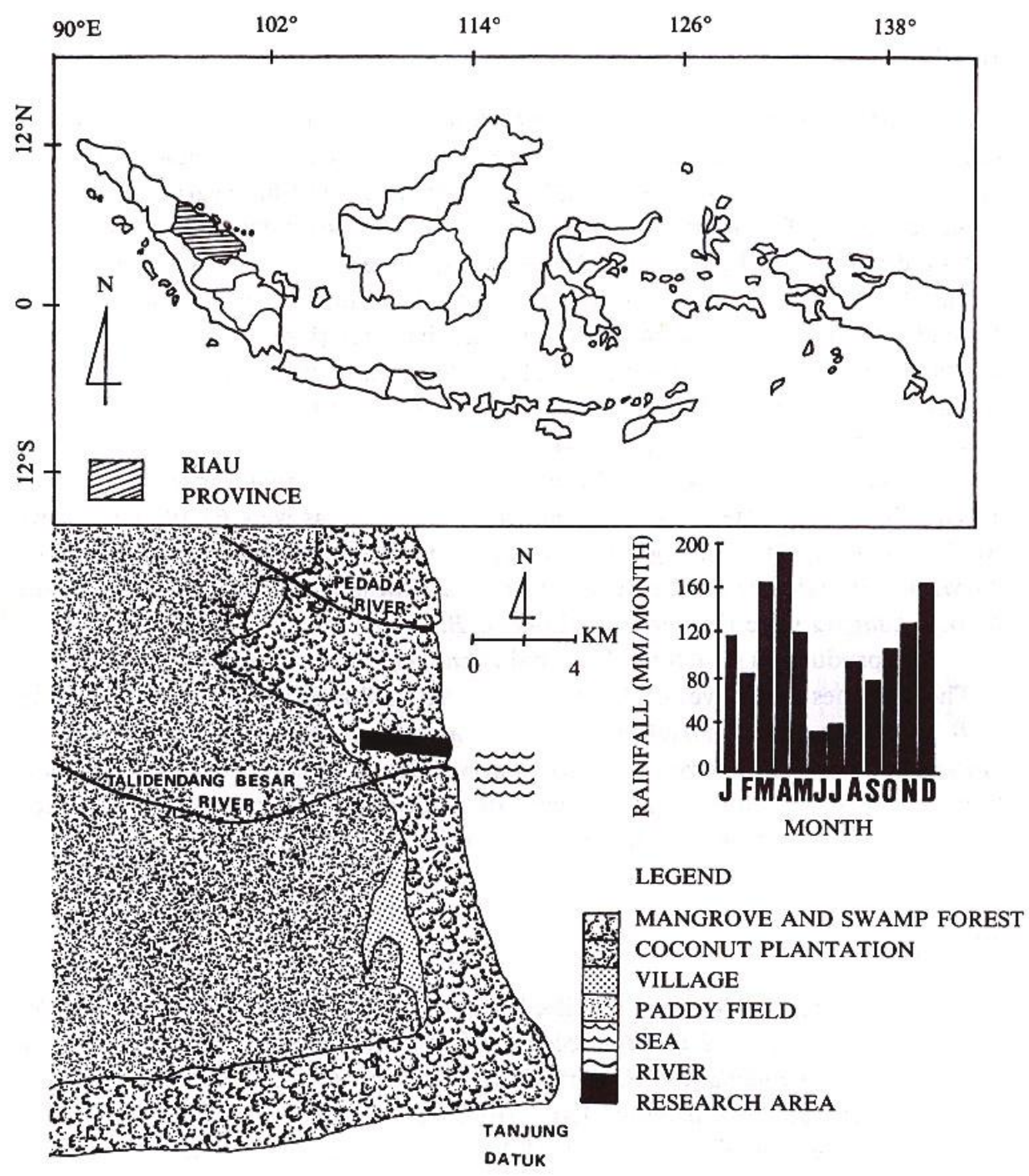

Figure 1. Location and climatic diagram of the research area 


\section{RESULTS AND DISCUSSION}

\section{Results}

Tables 1, 2 and 3 show the estimated aboveground biomass of anatomical organs of each tree, the leaf area and specific leaf area of a sample tree of $R$. apiculata, $B$. sexangula and B. parviflora, respectively. The aboveground biomass of sample trees of $R$. apiculata, B. sexangula and B. parviflora were estimated at $381 \mathrm{~kg} \mathrm{~d}$.wt, $387.70 \mathrm{~kg} \mathrm{~d}$.wt and $296.36 \mathrm{~kg} \mathrm{~d} . \mathrm{wt}$, respectively. Compared to the sample trees of $R$. apiculata and $B$. sexangula, a sample tree of $B$. parviflora has a smaller aboveground biomass, although its diameter $(\mathrm{DBH})$ was similar to the sample trees of the two former species. The leaves as a photosynthetic part contributed very little to biomass matters, i.e. $2.48 \%, 3.61 \%$ and $4.48 \%$ for $R$. apiculata, B. sexangula and B. parviflora, respectively. The total leaf area as well as the mean specific leaf area of $R$. apiculata were smaller than those of the other species. It was estimated that the mean specific leaf areas were $61.19 \mathrm{cmVg}$ d.wt for $R$. apiculata, $77.57 \mathrm{cmVg}$ d.wt for $B$. sexangula, and $80.80 \mathrm{cmVg} \mathrm{d}$.wt for $B$. parviflora. It indicates that the leaves of $R$. apiculata were thickest, while the leaves of $B$. sexangula were thicker than those of $B$. parviflora.

The production structure of the main commercial trfee species is shown in Fig. 2. The branches and leaves of $R$. apiculata were shallower and sparser than those of $B$. sexangula and B. parviflora. The large amount of leaves and branches of $R$. apiculata in the stem horizon of 13 to $14 \mathrm{~m}$ was due to the existence of large main branches with a diameter of $13.5 \mathrm{~cm}$. In addition, B. sexangula has a larger proportion of branches than the other species.

\section{Discussion}

As indicated by the mean specific leaf area (Table 1) and vertical production structure (Fig. 2), R. apiculata is recognized to have a sparser foliage of thicker leaves than B. sexangula and B. parviflora. It is suggested that one characteristic of/?, apiculata is to be a shade-intolerant tree species as reported by Macnae (1968). In the mangrove forest of Halmahera, Maluku Province in Indonesia, Komiyama et al. (1988) reported that $R$. apiculata has a sparser foliage of thicker leaves than B. gymnorrhiza. Similar results were also reported by Ninomiya et al. (1989) for $R$. stylosa and B. gymnorrhiza in the mangrove forest of Funaura Bay, Iriomote Island in Okinawa, and by Nakasuga (1979) for $R$. mucronata and B. conjugata in the Ryukyu Islands, Southern Japan. 
Production structure of main commercial tree species - Cecep Kusmana \& Hiroyuki Watanabe

Table 1. Estimated aboveground biomass, leaf area (LA) and specific leaf area (SLA) of the sample tree of Rhizophora apiculata

\begin{tabular}{|c|c|c|c|c|c|c|c|c|}
\hline \multirow{2}{*}{$\begin{array}{l}\text { Horizon } \\
\text { (m) }\end{array}$} & \multicolumn{6}{|c|}{ Aboveground biomass (kg d.wt) } & \multirow{2}{*}{$\begin{array}{l}\text { LA } \\
-\left(\mathrm{m}^{2}\right)\end{array}$} & \multirow{2}{*}{$\begin{array}{l}\text { SLA } \\
\left(\mathrm{cm}^{2} / \mathrm{g} \text { d.wt }\right)\end{array}$} \\
\hline & $\overline{\text { Leaf }}$ & $\begin{array}{l}\text { Flowers and } \\
\text { fruits }\end{array}$ & Branch & Stem & Prop-roots & Total & & \\
\hline$\overline{0-1}$ & & & & 9.57 & 16.74 & 26.31 & & \\
\hline $1-2$ & & & & 22.65 & 13.77 & 36.42 & & \\
\hline $2-3$ & & & & 22.33 & 22.33 & & & \\
\hline 3- 4 & & & & 19.46 & 19.46 & & & \\
\hline 4- 5 & & & & 18.82 & 18.82 & & & \\
\hline $5-6$ & & & & 18.82 & 18.82 & & & \\
\hline $6-7$ & & & & 18.50 & 18.50 & & & \\
\hline $7-g$ & 0.07 & 0.01 & 6.68 & 16.59 & 23.35 & & 0.36 & 66.09 \\
\hline 8- 9 & & & & 16.27 & 16.27 & & & \\
\hline $9-10$ & 0.08 & 0.01 & 0.33 & 15.63 & 16.05 & & 0.52 & 62.23 \\
\hline $10-11$ & & & & 14.36 & 14.36 & & & \\
\hline $11-12$ & & & & 14.67 & 14.67 & & & \\
\hline $12-13$ & & & & 12.44 & 12.44 & & & \\
\hline $13-14$ & 5.34 & 0.71 & 63.67 & 10.53 & 80.25 & & 21.15 & 50.49 \\
\hline $14-15$ & 0.03 & 0.01 & 0.17 & 5.42 & 5.63 & & 0.09 & 67.87 \\
\hline $15-16$ & & & & 5.30 & 5.30 & & & \\
\hline $16-17$ & 0.14 & 0.01 & 0.45 & 4.72 & 5.32 & & 0.62 & 50.38 \\
\hline $17-18$ & 0.45 & 0.04 & 1.67 & 4.15 & 6.31 & & 2.08 & 50.43 \\
\hline $18-19$ & 0.50 & 0.07 & 2.17 & 3.13 & 5.87 & & 2.12 & 68.11 \\
\hline $19-20$ & 1.37 & 0.16 & 4.07 & 2.04 & 7.64 & & 6.44 & 63.37 \\
\hline $20-21$ & 0.71 & 0.10 & 1.70 & 1.40 & 3.91 & & 3.63 & 62.56 \\
\hline $21-22$ & 0.59 & 0.11 & 1.11 & 0.64 & 2.45 & & 2.46 & 63.87 \\
\hline $22-22.8$ & 0.17 & 0.03 & 0.18 & 0.14 & 0.52 & & 0.68 & 67.68 \\
\hline Total & 9.45 & 1.26 & 82.20 & 257.58 & 30.51 & 381.00 & 40.15 & 673.08 \\
\hline Average & & & & & & & & 61.19 \\
\hline
\end{tabular}

The prop-roots constituted about $8 \%$ of the aboveground biomass of a sample tree of R. apiculata. It is supposed that in this area the stand of R. apiculata grows in estuarine conditions. Lugo and Snedaker (1974) also reported the low proportion of prop-roots $(2 \%, 15 \%)$ in estuarine forest in the mangroves of Florida. In addition, Christensen (1978) stated that the small proportion of prop-roots of Rhizophora stand growing in the estuarine conditions might be due to a better nutrient supply or reduced salinity regime.

The existence of the prop-roots on the stem may be regarded as a characteristic to distinguish the production structure of $R$. apiculata from that of $B$. sexangula and $B$. parviflora. On the other hand, B. parviflora and $B$. sexangula tended to have a greater proportion of leaves and branches along the stem than $R$. apiculata. 
Table 2. Estimated aboveground biomass, leaf area (LA), and specific leaf area (SLA) of the sample tree of Bruguiera sexangula

\begin{tabular}{|c|c|c|c|c|c|c|c|}
\hline \multirow{2}{*}{$\begin{array}{l}\text { Horizon } \\
(\mathrm{m})\end{array}$} & \multicolumn{5}{|c|}{ Aboveground biomass (kg d.wt) } & \multirow{2}{*}{$\begin{array}{l}\text { LA } \\
\left(\mathrm{m}^{2}\right)\end{array}$} & \multirow{2}{*}{$\begin{array}{c}\text { SLA } \\
\text { (cm²/g d.wt) }\end{array}$} \\
\hline & Leaf & Flowers and fruits & Branch & Stem & Total & & \\
\hline$\overline{0-1}$ & & & & 40.52 & 40.52 & & \\
\hline $1-2$ & & & & 23.73 & 23.73 & & \\
\hline $2-3$ & & & & 23.79 & 23.79 & & \\
\hline 3- 4 & & & & 21.90 & 21.90 & & \\
\hline 4- 5 & & & & 20.44 & 20.44 & & \\
\hline 5- 6 & 0.15 & 0.01 & 0.77 & 18.62 & 19.55 & 1.53 & 97.96 \\
\hline 6- 7 & & & & 17.16 & 17.16 & & \\
\hline $7-8$ & 0.21 & 0.03 & 2.71 & 18.25 & 21.20 & 2.34 & 79.87 \\
\hline 8- 9 & 0.46 & 0.05 & 3.84 & 17.16 & 21.51 & 4.36 & 75.73 \\
\hline $9-10$ & 0.27 & 0.04 & 2.07 & 15.70 & 18.08 & 2.55 & 77.36 \\
\hline $10-11$ & 2.86 & 0.37 & 29.68 & 16.79 & 49.70 & 21.22 & 80.49 \\
\hline $11-12$ & 4.09 & 0.61 & 39.65 & 12.05 & 56.40 & 21.48 & 74.75 \\
\hline $12-13$ & 0.14 & 0.02 & 0.89 & 6.75 & 7.80 & 1.51 & 75.29 \\
\hline $13-14$ & 1.69 & 0.27 & 11.21 & 5.48 & 18.65 & 10.86 & 80.41 \\
\hline $14-15$ & 1.62 & 0.24 & 6.93 & 3.87 & 12.66 & 9.59 & 74.99 \\
\hline $15-16$ & 1.56 & 0.34 & 6.84 & 1.61 & 10.35 & 8.83 & 71.12 \\
\hline $16-17$ & 0.11 & 0.12 & 2.04 & 0.91 & 3.88 & 5.54 & 72.84 \\
\hline $17-17.6$ & 0.14 & 0.02 & 0.15 & 0.07 & 0.38 & 0.70 & 70.05 \\
\hline Total & 14.00 & 2.12 & 106.78 & 264.80 & 387.70 & 90.51 & 930.86 \\
\hline$\overline{\text { Average }}$ & & & & & & & 77.57 \\
\hline
\end{tabular}

\section{CONCLUSION}

While the leaves of B. parviflora were thinner than those of B. sexangula, Rhizophora apiculata has a sparser foliage of thicker leaves than the two former tree species. In addition, either $B$. parviflora or $B$. sexangula has a larger proportion of leaves and branches along the stem than $R$. apiculata. It is suggested that one characteristic of $R$. apiculata is a shade-intolerant tree species whereas B. parviflora and B. sexangula are shade-tolerant tree species. 
Production structure of main commercial tree species - Cecep Kusmana \& Hiroyuki Watanabe

Table 3. Estimated aboveground biomass, leaf area (LA), and specific leaf area (SLA) of the sample tree of Bruguiera parviflora

\begin{tabular}{|c|c|c|c|c|c|c|c|}
\hline \multirow{2}{*}{$\begin{array}{l}\text { Horizon } \\
\text { (m) }\end{array}$} & \multicolumn{5}{|c|}{ Aboveground biomass (kg d.wt) } & \multirow{2}{*}{$\begin{array}{l}\mathrm{LA} \\
\left(\mathrm{m}^{2}\right)\end{array}$} & \multirow{2}{*}{$\begin{array}{c}\text { SLA } \\
\left(\mathrm{cm}^{2} / \mathrm{g} \text { d.wt }\right)\end{array}$} \\
\hline & Leaf & Flowers and fruits & Branch & Stem & Total & & \\
\hline$\overline{0-1}$ & & & & 28.81 & 28.81 & & \\
\hline $1-2$ & & & & 21.11 & 21.11 & & \\
\hline $2-3$ & & & & 18.43 & 18.43 & & \\
\hline 3- 4 & & & & 17.76 & 17.76 & & \\
\hline 4- 5 & & & & 17.42 & 17.42 & & \\
\hline $5-6$ & & & & 16.08 & 16.08 & & \\
\hline $6-7$ & & & & 15.08 & 15.08 & & \\
\hline 7- 8 & & & & 14.41 & 14.41 & & \\
\hline $8-9$ & 0.50 & 0.07 & 4.43 & 13.40 & 18.40 & 5.41 & 109.16 \\
\hline $9-10$ & 4.30 & 0.39 & 23.78 & 12.40 & 40.87 & 31.89 & 73.13 \\
\hline $10-11$ & 0.64 & 0.11 & 2.71 & 9.72 & 13.18 & 5.04 & 81.96 \\
\hline $11-12$ & & & & 8.71 & 8.71 & & \\
\hline $12-13$ & 0.09 & 0.02 & 0.21 & 7.71 & 8.03 & 0.73 & 99.01 \\
\hline $13-14$ & 1.66 & 0.32 & 9.68 & 8.04 & 19.70 & 14.36 & 85.18 \\
\hline $14-15$ & 1.99 & 0.35 & 8.64 & 4.69 & 15.67 & 12.91 & 75.75 \\
\hline $15-16$ & 1.11 & 0.22 & 4.43 & 3.02 & 8.78 & 6.97 & 71.12 \\
\hline $16-17$ & 2.06 & 0.45 & 6.23 & 1.34 & 10.08 & 13.50 & 85.03 \\
\hline $17-18$ & 0.83 & 0.18 & 1.80 & 0.67 & 3.48 & 5.56 & 73.67 \\
\hline $18-19$ & 0.08 & 0.01 & 0.11 & 0.10 & 0.30 & 0.47 & 68.36 \\
\hline $19-19.4$ & 0.03 & 0.01 & 0.01 & 0.01 & 0.06 & 0.15 & 66.47 \\
\hline$\overline{\text { Total }}$ & 13.29 & 2.13 & 62.03 & 218.91 & 296.36 & 96.99 & 888.84 \\
\hline$\overline{\text { Average }}$ & & & & & & & 80.80 \\
\hline
\end{tabular}

\section{ACKNOWLEDGEMENTS}

We wish to thank Mr. Subkhan, student of the Faculty of Forestry, Bogor Agricultural University for helping in the collection of data in the field; Dr. Dudung Darusman, Dean of the Faculty of Forestry, Bogor Agricultural University for his kind assistance in providing admission letters; Prof .Dr. Ishemat Soerianegara and Ir. Syafii Manan, MSc., Faculty of Forestry, Bogor Agricultural University for their encouragement throughout this research. 
BIOTROPIA No. 5, 1991/1992

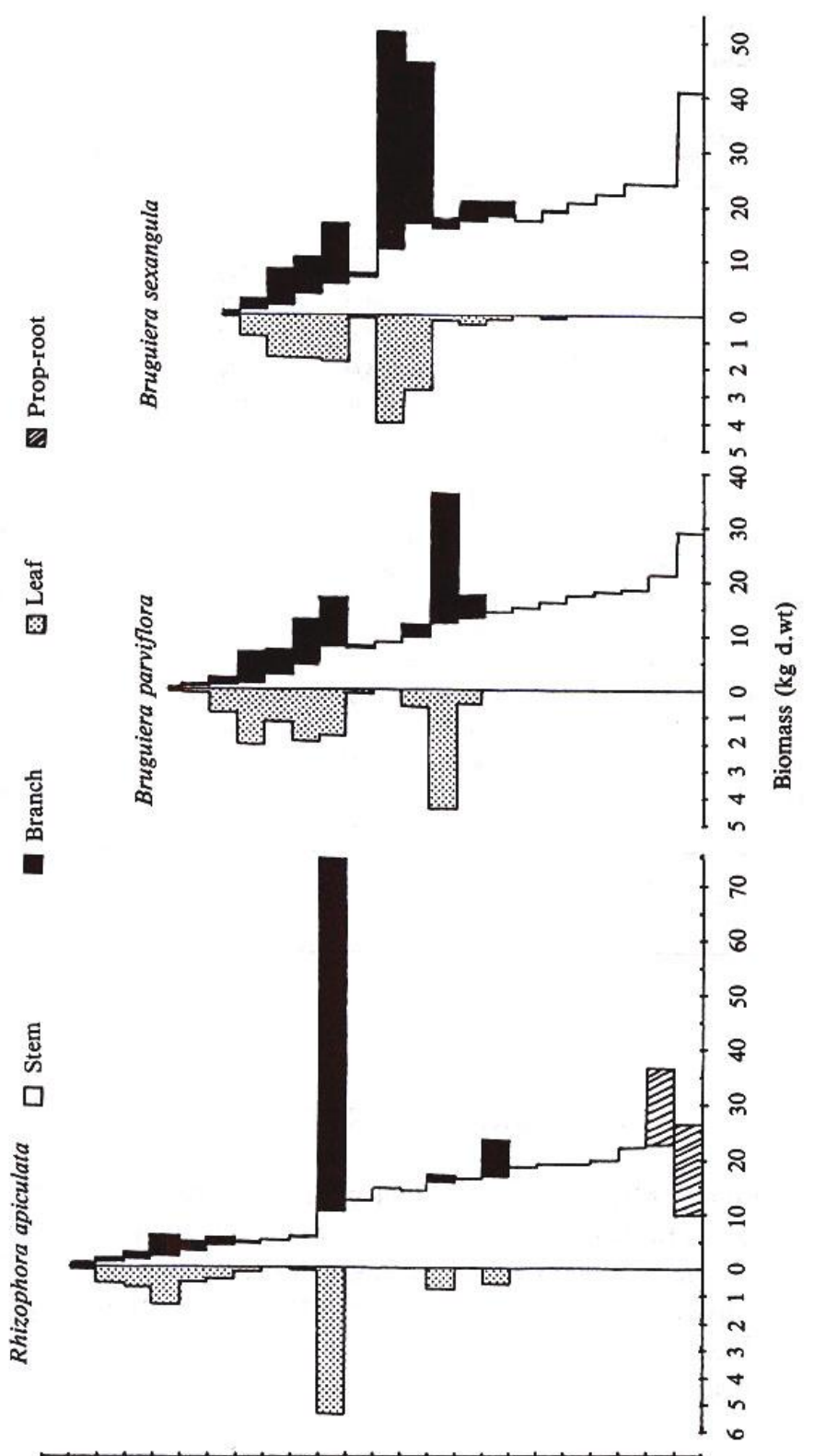

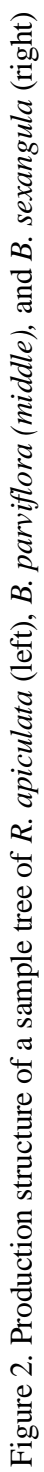

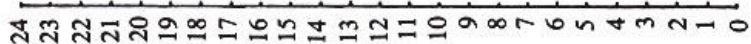

(w) $า น ช ิ เ$ 
Production structure of main commercial tree species - Cecep Kusmana \& Hiroyuki Watanabe

\section{REFERENCES}

CHRISTENSEN, B. 1978. Biomass and primary production of Rhizophora apiculata Bl. in a mangrove in Southern Thailand.

Aquatic Botany 4: 43-52. DARSIDI, A. 1984. Mangrove forest management in Indonesia. In: Soemodihardjo, S., I. Soerianegara,

M. Sutisna, K. Kartawinata, Supardi, N. Naamin and H. Al Rasyid (eds.), Proceedings Symposium II on Mangrove Ecosystem: p. 27-37. MAB, LIPI, Jakarta.

KOMIYAMA, A., H. MORIYA, S. PRAWIROATMODJO, T. TOMA and K. OGINO. 1988. Forest as an ecosystem, its structure and function: 2. Primary productivity of mangrove forest. In: K. Ogino and M. Chihara (eds.), Biological System of Mangroves: A Report of East Indonesian Mangrove Expedition 1986: 97-106. Ehime University, Ehime, Japan.

Luoo, A.E. and S.C. SNEDAKER. 1974. The ecology of mangroves. Ann. Rev. Ecol. Syst. 5: 39-65.

MACNAE, W. 1968. A general account of the fauna and flora of mangrove swamps and forests in the Indo West Pacific region. Adv. Mar. Biol. 6: 73-270.

NAKASUGA, T. 1979. Analysis of the mangrove stand. Sci. Bull. Coll. Agric. Univ. Ryukyus 26: 413519 (in Japanese with English summary).

NINOMIYA, I., A. KOMIYAMA, H. MORIYA, Y. TADAKI, and K. OGINO. 1989. Production structure of Rhizophora stylosa and Bruguiera gymnorrhiza in Funaura, Iriomote. Galaxea 8: 65-68. SCHMIDT, F.H. and J.H.A. FERGUSON. 1951. Rainfall type based on wet and dry period ratios of Indonesia with western New Guinea. Verhandelingen No. 42, Kementrian Perhubungan, Djawatan Meteorologi dan Geofisika, Jakarta. 77 p.

SOEGIARTO, A. 1979. The Indonesian marine environment: its problems and management. Ber. Ilmu Peng. Teknol. 23 (1): 9-21. 